\title{
Breast cancer drug delivery by novel drug-loaded chitosan-coated magnetic nanoparticles
}

\author{
A. Taherian ${ }^{1}$, N. Esfandiari ${ }^{*}$ (D) and S. Rouhani ${ }^{2}$
}

\author{
*Correspondence: \\ ne_esfandiari@sbu.ac.ir \\ ${ }^{1}$ Faculty of Life Sciences \\ and Biotechnology, Shahid \\ Beheshti University, Tehran, \\ Iran \\ Full list of author information \\ is available at the end of the \\ article
}

\begin{abstract}
Background: Breast cancer is one of the most challenging cancers among women which is considered one of the most lethal cancers to this date. From the time that cancer has been discovered, finding the best therapeutic method is still an ongoing process. As a novel therapeutic method, nanomedicine has brought a vast number of materials that could versatilely be used as a drug carrier. The purpose of this study is to develop a novel black pomegranate peel extract loaded with chitosan-coated magnetic nanoparticles to treat breast cancer cells.

Results: The morphology and size distribution of the nanoparticles studied by dynamic light scattering, atomic force microscopy, scanning, and transitional electron microscopy showed the spherical shape of the nanoparticles and their promising size range. Studies by Fourier transform infrared spectroscopy, X-ray diffraction, vibrating sample magnetometer, and zeta sizer confirmed the synthesis, substantial crystallinity, magnetic potential of the nanoparticles, and their satisfactory stability. The DPPH assay revealed that the obtained black pomegranate peel extract has $60 \%$ free radical scavenging activity. The cytotoxicity studies by MTT and LDH assay carried out on $\mathrm{NIH} / 3 \mathrm{~T} 3, \mathrm{MBA}-\mathrm{MB}-231$, and $4 \mathrm{~T} 1$ cells confirmed that the magnetic nanoparticles had no significant cytotoxicity on the cells. However, the drug-loaded nanoparticles could significantly eradicate cancerous cells which had more efficiency comparing to free drug. Furthermore, free drug and drug-loaded nanoparticles had no toxic effect on normal cells.
\end{abstract}

Conclusion: Owing to the results achieved from this study, the novel drug-loaded nanoparticles are compatible to be used for breast cancer treatment and could potentially be used for further in vivo studies.

Keywords: Chitosan-coated magnetic nanoparticles, Black pomegranate peel extract, Drug delivery, Breast cancer

\section{Background}

Cancer, a scope of abnormalities in cell proliferation that have caused considerable concern over public health. What makes cancer the major public health issue could potentially be a phenomenon called "metastasis", in which the cancerous cells achieve the included in the article's Creative Commons licence and your intended use is not permitted by statutory regulation or exceeds the permitted use, you will need to obtain permission directly from the copyright holder. To view a copy of this licence, visit http://creativecommons.org/ licenses/by/4.0/. The Creative Commons Public Domain Dedication waiver (http://creativecommons.org/publicdomain/zero/1.0/) applies to the data made available in this article, unless otherwise stated in a credit line to the data. 
capability to migrate distant regions of the body (Lee et al. 2017; Gurunathan et al. 2018; Senapati et al. 2018; Esfandiari and Taherian 2019). According to the latest reports of the World Health Organization (WHO), cancer has retained its place as a leading cause of death in most countries (Wild et al. 2020). It has also been announced that in 2018, the new cancer cases would reach 18.1 million and the death reports would rise to 9.6 million. Among cancer reports, lung cancer and female breast cancer are the two most life-threatening cancers. Breast cancer is one of the frequently diagnosed and the leading causes of death among women (Bray et al. 2018). Due to the reports that have been gathered from the American Cancer Society (ACS) since 2015, breast cancer incidence and death due to breast cancer estimations have increased annually in the United States (Siegel et al. 2015, 2016, 2017, 2018, 2019, 2020).

As for therapeutics, surgery including mastectomy and lumpectomy, radiotherapy, chemotherapy, and endocrine therapy are the ongoing strategies being carried out for breast cancer treatment (Tang et al. 2017). Due to the limitations of the ongoing strategies for breast cancer treatment, the development of a highly specific and promoted strategy should be at the highest level of priority.

Recently, employing nanotechnology to improve drug delivery strategies for cancer treatment and diagnosis has gained significant attention in preclinical studies (Esfandiari 2018; Sanaeimehr et al. 2018). Nanomedicine is a field of science that exploits pharmaceutical and nanoscience. It utilizes materials including organic and inorganic such as polymeric and metallic structures in nano-scale, also known as nanoparticles (NPs), to enhance the efficiency of drug delivery methods (Esfandiari et al. 2016; Hartshorn et al. 2018; Singh et al. 2019). The development of such structure can result in improvement of the drug therapeutic index, targeted delivery, and controlled release of the drug. It could also enhance the pharmaceutical properties of the drug such as stability, solubility, and circulating half-life (Shi et al. 2017; Esfandiari et al. 2018). To this date, numerous nanomedicines are being used as therapeutics. The NPs that have currently been approved are liposomal doxorubicin used for Kaposi's sarcoma with an increase of drug delivery to the tumor site and low systemic cytotoxicity and leuprolide acetate and polymer (PLGH (poly (DL-lactide-coglycolide)) for prostate cancer by having prolonged circulation time. Moreover, albumin-bound paclitaxel has provided an enhancement in drug solubility and delivery for breast and pancreatic cancer and iron oxide NPs that have been used for glioblastoma by having enhanced cellular uptake and diagnosis application in imaging, etc. (Bobo et al. 2016).

Among all nano-sized materials, magnetic nanoparticles (MNPs), especially superparamagnetic iron oxide nanoparticles (SPIONs), are at the top of the biomedical research trends (Kayal and Ramanujan 2010; Erofeev et al. 2018). They are also known as theranostic nanoparticles or nanotheranostics. Theranostic encompasses both therapeutic and diagnostic functionality. In addition to their therapeutic application, they are highly applicable in diagnostic moieties such as positron emission tomography, magnetic resonance imaging (MRI), ultrasonic imaging, computed tomography, photoacoustic imaging (Fernandes and Kolios 2019a), and optical imaging (Chen et al. 2017). In diagnosis moiety, the use of MNPs in MRI could for instance make it possible to detect liver cancer and metastatic lymph node at the early stages when other contrast images were incapable of visualizing them (Gobbo et al. 2015). In the case of therapeutic functionality of 
the MNPs, they have a large surface-to-volume ratio that gives them the ability to carry a variety of therapeutic, targeting, or contrast agents, functional at the cellular level, promising biocompatibility, and unique magnetic response (Xiong et al. 2018; Fernandes and Kolios 2019b).

Magnetite $\left(\mathrm{Fe}_{3} \mathrm{O}_{4}\right)$, due to the presence of $\mathrm{Fe}^{2+}$ and its electron donation potential, and maghemite $\left(\gamma-\mathrm{Fe}_{2} \mathrm{O}_{3}\right)$ are the two frequently used materials to form SPIONs. They could be used as drug carriers and other biomedical research such as tissue repair and hyperthermia (Patra et al. 2010; Mohammed et al. 2017a; Wu and Huang 2017; Erofeev et al. 2018).

Followed by MNPs, polymeric NPs have also gained researchers' interest owing to their promising biocompatibility, biodegradability, and their abundance in nature (Mohammed et al. 2017b). Despite a vast number of polymeric materials, chitosan NPs have broadly been studied due to their exclusive chemical properties and applications (Chanphai and Tajmir-Riahi 2016). Chitosan is a linear carbohydrate-backboned biopolymer that contains $\mathrm{N}$-acetyl-D-glucosamine and $\mathrm{D}$-glucosamine repeating units. Owing to its active amino groups, chitosan could be named as a versatile biopolymer. In addition to chitosan's antimicrobial activity, mucoadhesivity, and antitumor activity, it could be used as a great drug carrier (Zhao et al. 2018; Wiranowska et al. 2020).

In the past few years, medical researchers have investigated medicinal plants to find a novel anticancer drug. For this purpose, the compounds derived from the plant parts have been isolated and studied on cells to hinder the proliferation and metastasis of cancerous cells. Through a large number of medicinal plants, pomegranate has gained much more focus (Panth et al. 2017). Pomegranate (Punica granatum), as a member of Punicaceae family, is a fruit with a variety of therapeutic properties. Although it extensively grows in tropical and subtropical zones such as California, Turkey, Egypt, and Spain, pomegranate is intrinsically native to Iran which accounts as the largest producer (47\% of annual production) and exporter in the world (Fischer et al. 2011; Ambigaipalan et al. 2016). Pomegranate, especially its peel, contains a variety of bioactive compounds such as tannins, flavonoids, polyphenols, anthocyanins, etc. (Deng et al. 2017). Owing to the existing compounds in pomegranate, it has pharmacological and toxicological characteristics such as antioxidant (Chidambara Murthy et al. 2002), anti-inflammatory (Larrosa et al. 2010), anticancer, anti-angiogenesis, and antibacterial activity (Kanatt et al. 2010; Fawole et al. 2012). As a result of studies carried out on the anticancer activity of this fruit, pomegranate could inhibit proliferation and metastasis of cancerous cells, especially breast cancer (Vini and Sreeja 2015). Among the Punicaceae family cultivates, black peel pomegranate (BPP), also known as black pomegranate (BP), is an Iranianbased cultivate of this fruit that has been given less attention, and studies on the anticancer properties of such plant are still inadequate. Since flavonoids such as anthocyanins could be found in red, blue, and purple plant pigments (Mazza and Miniati 2018), it could be determined that black peel pomegranate has a higher amount of such compounds. Therefore, it could be more efficient for therapeutic purposes (Khorrami et al. 2019).

In this study, chitosan-coated magnetic nanoparticles (CCMNPs) were synthesized by a two-step precipitation method. As a novel anticancer drug, black pomegranate peel extract (BPPE) was loaded into the nanocomposites to develop a treatment for breast 

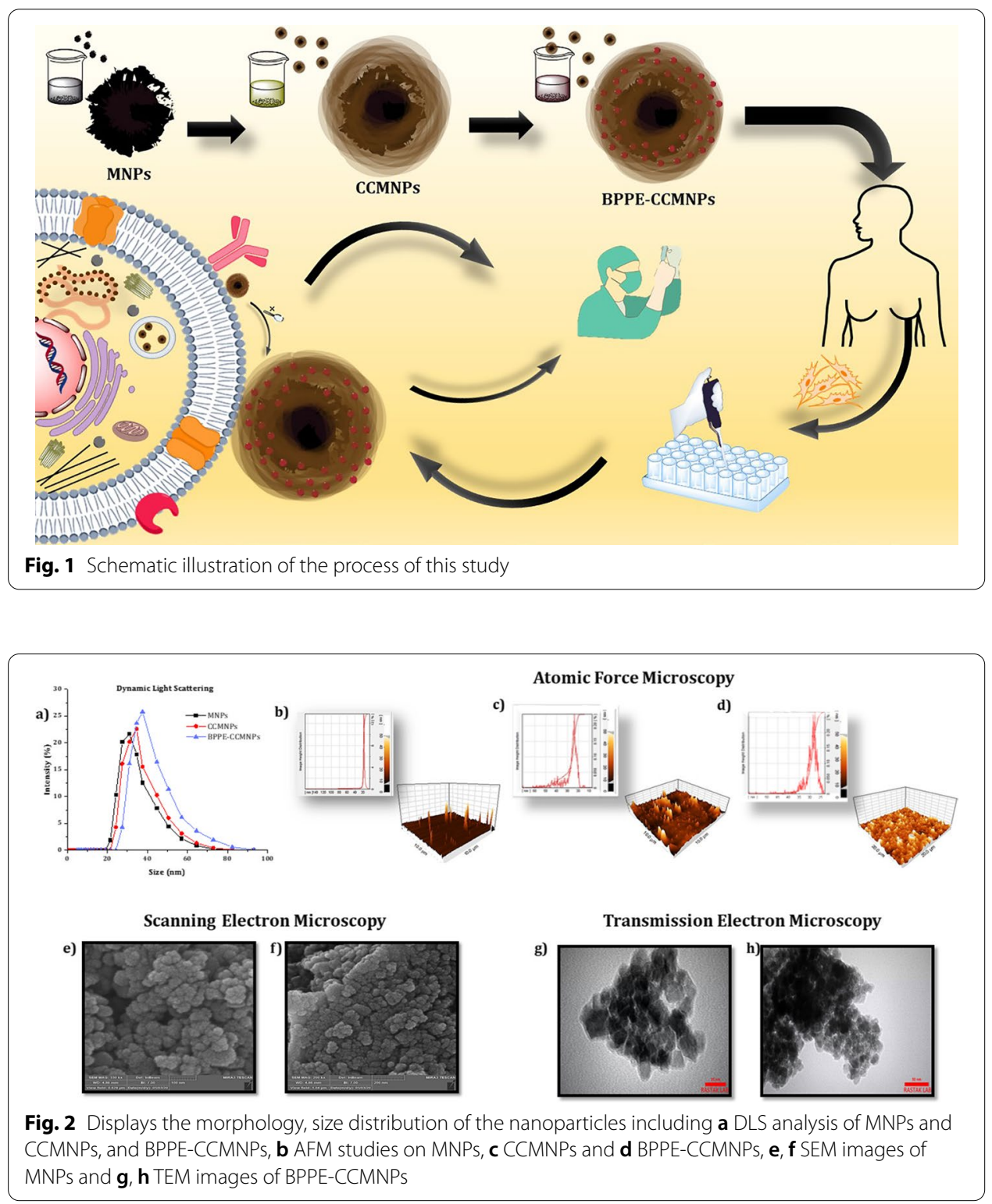

cancer. The cytotoxicity of the novel black pomegranate peel extract loaded with chitosan-coated magnetic nanoparticles (BPPE-CCMNPs) as the drug-loaded NPs, free BPEE as free drug, and blank MNPs as uncoated and unloaded NPs were assessed on MDA-MB-231 and 4T1 breast cancer cells and NIH/3T3 as a normal fibroblastic cell (Fig. 1).

\section{Results}

\section{Morphology and size distribution of the nanoparticles}

The results achieved from dynamic light scattering (DLS) analysis (Fig. 2a) showed that the uncoated MNPs have a mean size of $30.3 \pm 7.1 \mathrm{~nm}$. Moreover, after coating chitosan, the size range has changed to $34.2 \pm 8.4 \mathrm{~nm}$ which approves the presence of a new layer on MNPs. The drug loading also caused NPs to be $37.3 \pm 6 \mathrm{~nm}$ in diameter. Morphology 
studies by atomic force microscopy (AFM) exhibit that the MNPs have a height distribution of about $20 \pm 3.3 \mathrm{~nm}$ (Fig. 2b). Followed by the coating step, the height distribution of the CCMNPs has changed to $25 \pm 3.6 \mathrm{~nm}$ (Fig. 2c). Also, the height distribution of the drug-loaded nanoparticles (BPPE-CCMNPs) has been recorded at about $30 \pm 2.9 \mathrm{~nm}$ (Fig. 2d). Scanning electron microscopy (SEM) images have revealed that the synthesized MNPs were moderately smooth and spherical in shape with an average size of $19.4 \pm 2.7 \mathrm{~nm}$ (Fig. 2e, f). The images taken by transmission electron microscopy (TEM) confirmed that the drug-loaded nanoparticles were also spherical and had a size average of $27.9 \pm 3.4 \mathrm{~nm}$ (Fig. $2 \mathrm{~g}$, h).

\section{Stability of the nanoparticles in cell media}

The stability of the nanoparticles was carried out by preparing $1 \mathrm{mg} / \mathrm{ml}$ of MNPs and BPPE-CCMNPs in specific serum-free and serum-containing cell media used for the cytotoxicity studies in this work and incubation of the solutions for $24 \mathrm{~h}$ and $48 \mathrm{~h}$ at $37{ }^{\circ} \mathrm{C}$ (Fig. 3). In serum-free Roswell Park Memorial Institute (RPMI) media, MNPs $(79.4 \pm 5 \mathrm{~nm}$ and $-21.3 \pm 2 \mathrm{mV}$ at $24 \mathrm{~h}, 86 \pm 5 \mathrm{~nm}$ and $-13 \pm 1.8 \mathrm{mV}$ at $48 \mathrm{~h}$ ) and BPPECCMNPs $(106 \pm 7 \mathrm{~nm}$ and $+5.3 \pm 2 \mathrm{mV}$ at $24 \mathrm{~h}, 114 \pm 7.6 \mathrm{~nm}$ and $2.7 \pm 3 \mathrm{mV}$ at $48 \mathrm{~h})$ formed large aggregates and their surface charge has been changed. However, BPPECCMNPs $(38.7 \pm 4.3 \mathrm{~nm}$ and $+40.3 \pm 2.1 \mathrm{mV}$ at $24 \mathrm{~h}, 39.4 \pm 4.7 \mathrm{~nm}$ and $+38.9 \pm 2.5 \mathrm{mV}$ at $48 \mathrm{~h}$ ) have maintained their stability in serum-containing RPMI and no significant size growth were observed. On the contrary, MNPs displayed more instability $(93 \pm 3.5 \mathrm{~nm}$ and $-12 \pm 1.2 \mathrm{mV}$ at $24 \mathrm{~h}, 102 \pm 5.1 \mathrm{~nm}$, and $-5.7 \pm 2.6 \mathrm{mV}$ at $48 \mathrm{~h}$ ) in serum-containing RPMI media, and significant size growth and surface charge changes were reported.
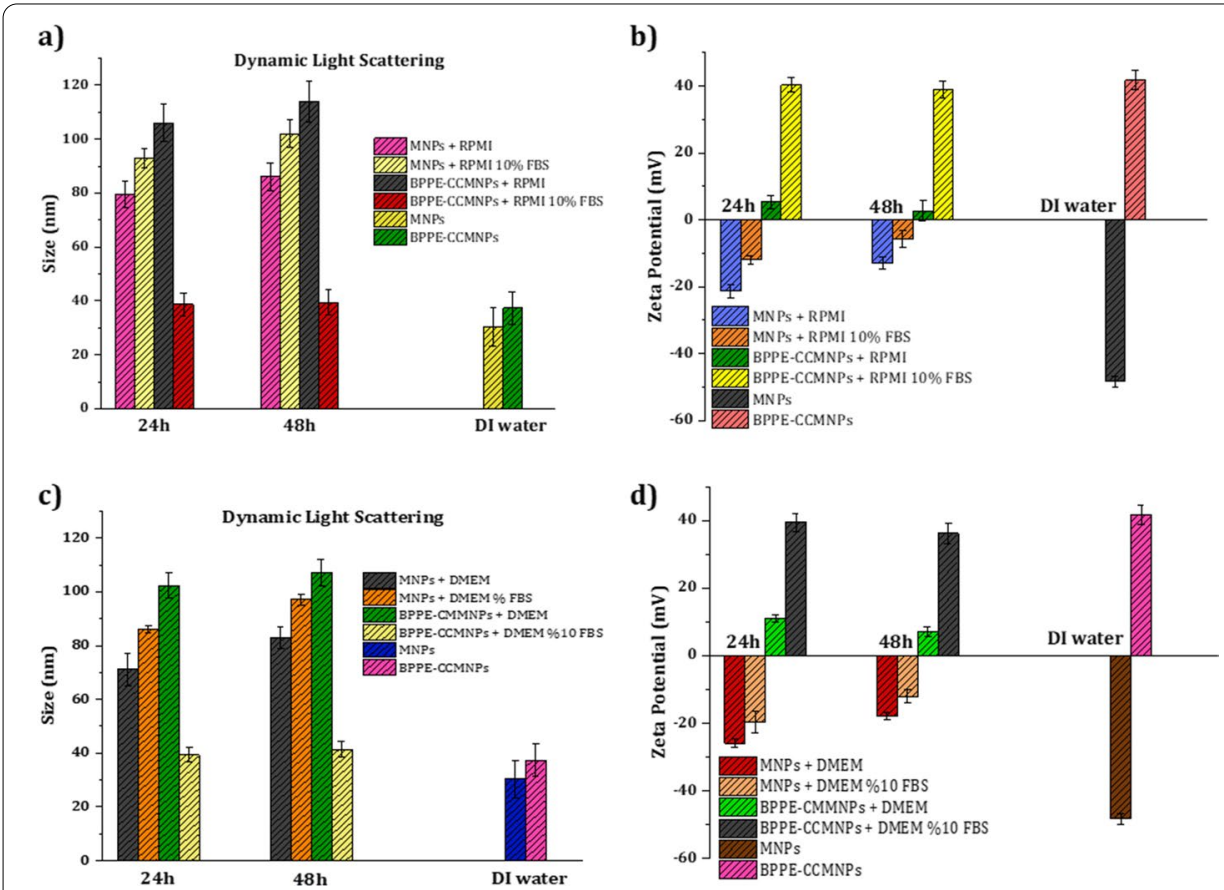

Fig. 3 Describes the stability of the MNPs and BPPE-CCMNPs in cell media. $\mathbf{a}, \mathbf{c}$ show DLS results and $\mathbf{b}, \mathbf{d}$ present the zeta potential of the nanoparticles in serum-free and serum-containing RPMI and DMEM cell media, respectively 
The hydrodynamic size and surface charge of MNPs and BPPE-CCMNPs in serum-containing and serum-free RPMI media are shown in Fig. 3a, b, respectively.

The stability results evaluated with serum-containing and serum-free Dulbecco's modified Eagle medium (DMEM) were similar to RPMI, but the changes were less intensive. The DLS and zeta potential results of the MNPs and BPPE-CCMNPs with serum-containing and serum-free DMEM media are shown in Fig. 3c, d, respectively. The DLS and zeta potential results of the MNPs and BPPE-CCMNPs in deionized water (DI water) are also shown in Fig. 3a-d, respectively, to compare the size and stability changes.

\section{Radical scavenging activity (RSA)}

The results of the 2,2-diphenyl-1-picryl-hydrazyl-hydrate (DPPH) free radical scavenging activity (Fig. 4) revealed that BPPE has the ability to eliminate $61.7 \%$ of the free radicals in the solutions. Furthermore, the half-maximal effective concentration (EC50) was recorded at about $7.81 \mu \mathrm{g} \mathrm{ml}^{-1}$.

\section{Structural characteristics and stability of the nanoparticles}

The surface functional groups of the MNPs, CCMNPs, and BPE-CCMNPs were confirmed by Fourier-transform infrared spectroscopy (FT-IR) analysis (Fig. 5a). The synthesis of MNPs was certified in all materials by two strong absorption bands at around 621 and $576 \mathrm{~cm}^{-1}$. The absorption bands a $576 \mathrm{~cm}^{-1}$, which presents $\mathrm{O}-\mathrm{H}$ stretching vibration, and $459 \mathrm{~cm}^{-1}$ are the characteristics of the tetrahedral and octahedral sites. Also, the band at $3430 \mathrm{~cm}^{-1}$ is due to the $\mathrm{O}-\mathrm{H}$ stretching vibration on the surface of the nanoparticles. In the matter of CCMNPs, the stretching $-\mathrm{CH}-$ vibration of chitosan was found at $2922 \mathrm{~cm}^{-1}$, and the absorption band at $1634 \mathrm{~cm}^{-1}$ is attributed to the $\mathrm{N}-\mathrm{H}$ vibration of coated chitosan. Moreover, the peaks at 1447 and $1076 \mathrm{~cm}^{-1}$ are relevant to the $\mathrm{C}-\mathrm{N}$ bond of the amino group and $\mathrm{C}-\mathrm{O}$ in the ether group of chitosan, respectively. The recorded peaks at 1445 and $1627 \mathrm{~cm}^{-1}$ indicate the $\mathrm{C}-\mathrm{C}$ stretching vibration of an aromatic ring. Also, the 1181 and $1055 \mathrm{~cm}^{-1}$ show the vibration of

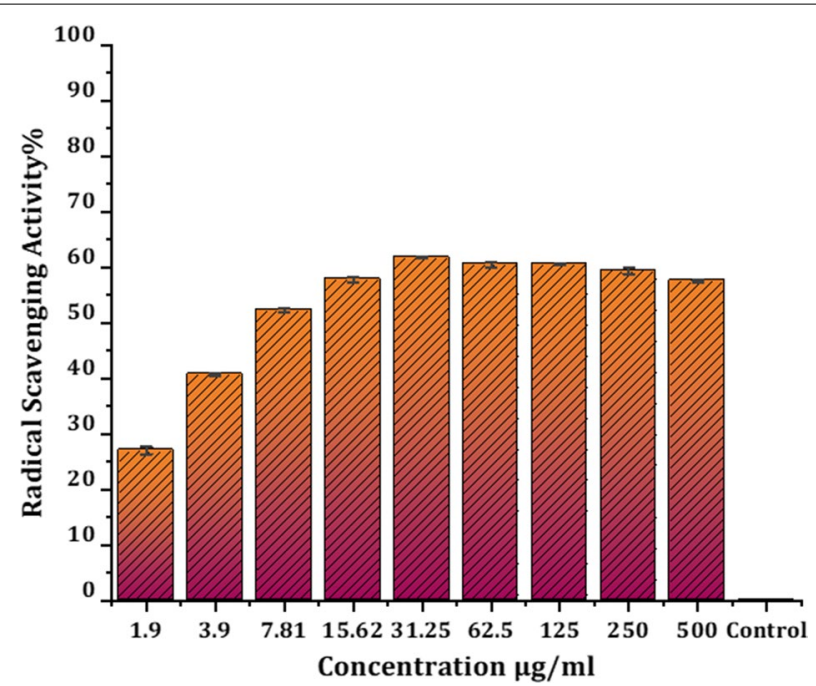

Fig. 4 Free radical scavenging of the prepared BPPE 

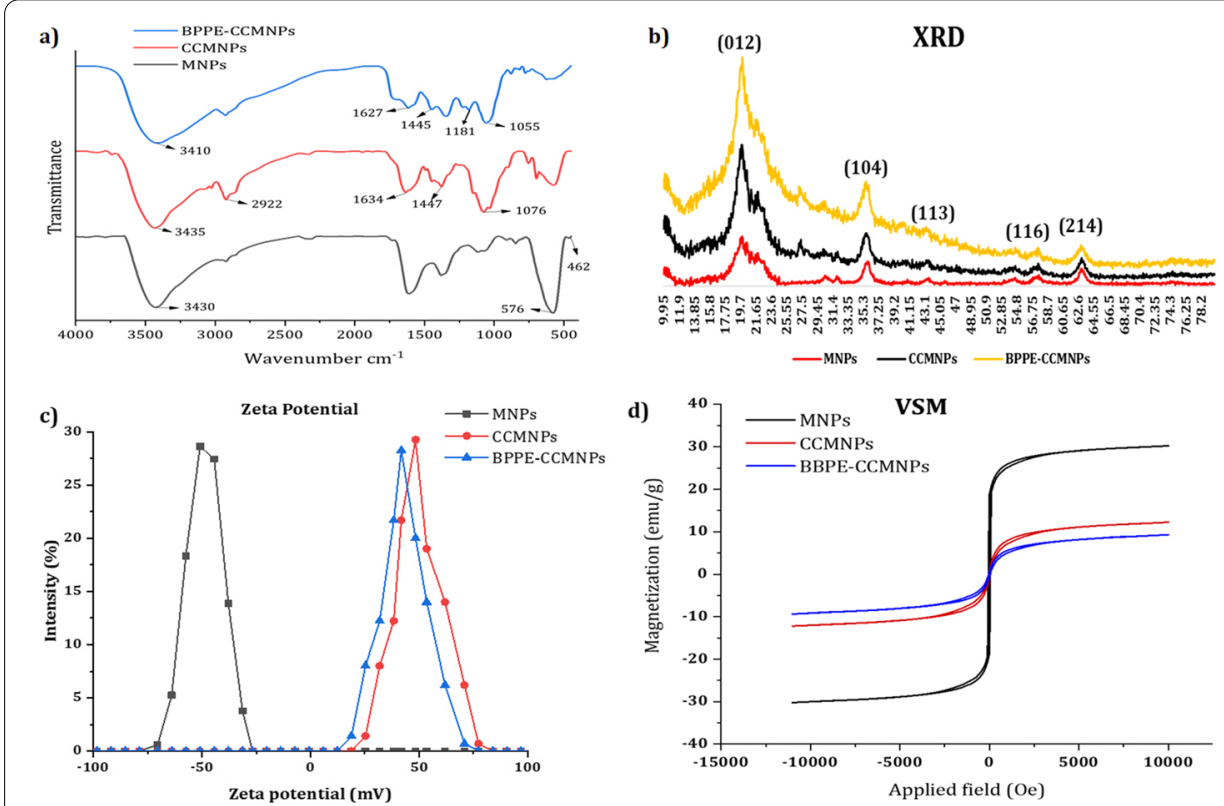

Fig. 5 Displays the structural characteristics of the nanoparticles that contain a FT-IR analysis, $\mathbf{b}$ XRD peaks, $\mathbf{c}$ the surface charge of MNPS, CCMNPS, and BPPE-CMMNPs by zeta sizer, and $\mathbf{d}$ VSM

the methyl phenyl ether group $\left(\mathrm{C}-\mathrm{O}-\mathrm{CH}_{3}\right)$ of the compound. The diffractogram of the MNPs, CCMNPs, and BPPE-CCMNPs is given in Fig. 5b. The founded diffraction peaks from X-ray diffraction (XRD) are the characteristics of the hematite $\left(\mathrm{Fe}_{2} \mathrm{O}_{3}\right)$ with rhombohedral structure. Also, the (012), (104), (113), (116), (214) repeated peaks recorded for the CCMNPs and BPPE-CCMNPs by the XRD analysis indicate the characteristics peaks of $\mathrm{Fe}_{2} \mathrm{O}_{3}$. The surface charge of the nanoparticles was assessed by a zeta sizer. The zeta potential of the MNPs was $-48.3 \pm 1.6 \mathrm{mV}$, after coating chitosan, it has been changed to $+44.6 \pm 3.5 \mathrm{mV}$, and after drug loading, it was $41.7 \pm 2.9$ (Fig. $5 \mathrm{c}$ ). The magnetic properties of the nanoparticles have been measured by a vibrating sample magnetometer (VSM) (Fig. 5d). The magnetic potential of the MNPs has been reported at $30.2 \mathrm{amu} / \mathrm{g}$. Followed by the chitosan coating step, the magnetic property of the CCMNPs has reduced to $12.2 \mathrm{emu} / \mathrm{g}$ and loading BPPE affects the magnetic potential to reach $9.3 \mathrm{emu} / \mathrm{g}$.

\section{In vitro drug loading and release}

The drug loading and release profile are shown in Fig. 6. The drug loading of the CCMNPs (Fig. 6a) has been carried out by measuring the residual drug in the supernatant. At the initial stage, the BPPE (about 30\%) molecules were rapidly absorbed by the nanoparticles. However, over time, the loading rate was gradually decreased until there were no significant changes from 120 to 180 min that could be the maximum loading efficiency of the CCMNPs. The loading capacity of the CCMNPs was $39.6 \pm 1.4 \%$ and their encapsulation efficiency was found to be $61 \pm 3.1 \%$.

The release profile of the BPPE-CCMNPs (Fig. 6b) was carried out by homogenizing the solutions in a shaker incubator at $37{ }^{\circ} \mathrm{C}$ and measuring the amount of released drug in the supernatant. BPPE release was investigated at $\mathrm{pH} 5,6.8$, and 7.4. An instant release 

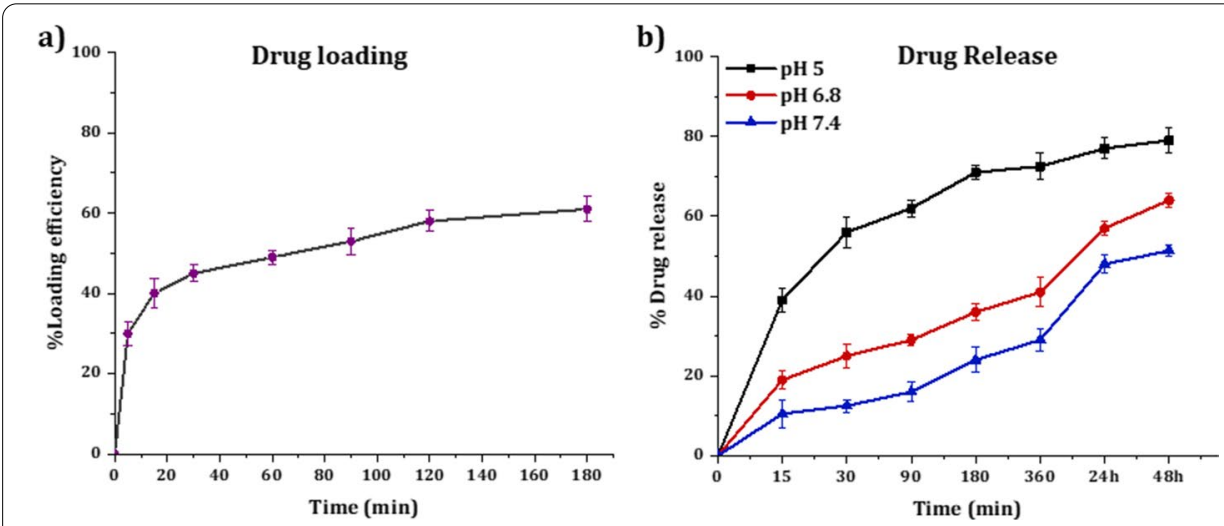

Fig. 6 a Drug loading and $\mathbf{b}$ release profile at $\mathrm{pH} 5,6.8$, and 7.4

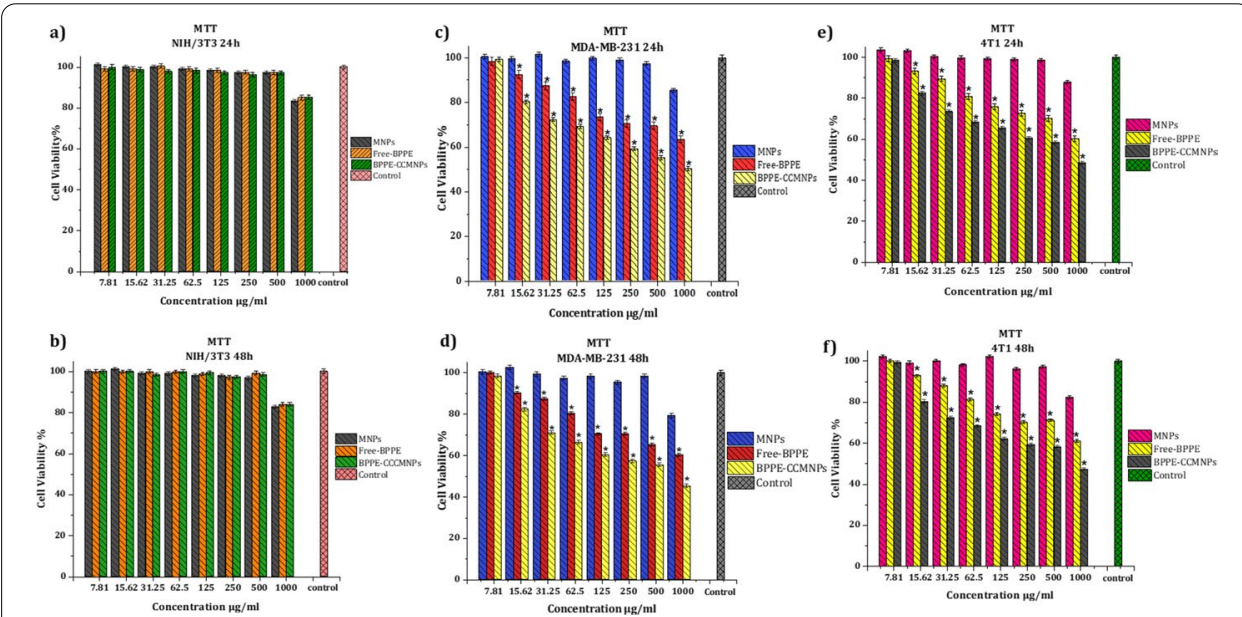

Fig. 7 Cytotoxicity effects of magnetic nanoparticles (MNPs), free black pomegranate peel extract (free BPPE), and black pomegranate peel extract loaded chitosan-coated magnetic nanoparticles (BPPE-CCMNPs) on $\mathbf{a}$, $\mathbf{b} \mathrm{NIH} / 3 \mathrm{~T} 3$, $\mathbf{c}$, d MDA-MB-231, and $\mathbf{e}$, f $4 \mathrm{~T} 1$ cells with 1000 to $7.81 \mu \mathrm{g} / \mathrm{ml}$ concentrations by serial dilution at $24 \mathrm{~h}$ and $48 \mathrm{~h}$ incubation. ${ }^{*} p \leq 0.05$ BPPE-CCMNPs versus free BPPE

of BPPE was observed in $15 \mathrm{~min}(33 \%)$ at $\mathrm{pH} 5$ and continued with a lower rate (compared to $15 \mathrm{~min}$ ) until there were no significant drug release changes observed from 24 to $48 \mathrm{~h}$. In contrast to release at $\mathrm{pH} 5$, BPPE release from nanoparticles initiated with a slower rate at $\mathrm{pH} 6.5(26 \%)$ and $\mathrm{pH} 7.4$ (12\%). At both $\mathrm{pH} 6.8$ and 7.4, the release rate was gradually increased until a burst release from $360 \mathrm{~min}$ to $24 \mathrm{~h}$ at both $\mathrm{pHs}$, but with a higher rate in $\mathrm{pH} 6.8$, were observed. In $24 \mathrm{~h}$ at $\mathrm{pH} 6.8$, the release rate increased from 57 to $64 \%$ while there were no significant changes observed at $\mathrm{pH} 7.4$. Nanoparticles have released about $79 \pm 3.1 \%, 64 \pm 1.7 \%$, and $51.4 \pm 1.5 \%$ of the BPPE at $\mathrm{pH} 5,6.8$, and 7.4, respectively.

\section{MTT assay}

The cytotoxicity of the MNPs, free-BPPE, and BPPE-CCMNPs which have individually been incubated with NIH/3T3 (Fig. 7a, b), MDA-MB-231 (Fig. 7c, d), and 4T1 (Fig. 7e, f), has been assessed by 3-(4,5-dimethylthiazol-2-yl)-2,5-diphenyltetrazolium bromide 
(MTT) assay. Herein, for each cell type study, the untreated cells containing fresh cell media have been selected as control.

It has been found that the synthesized MNPs from 7.81 to $500 \mu \mathrm{g} / \mathrm{ml}$ show no significant cytotoxicity when incubated with NIH/3T3, MDA-MB-231 and 4T1 cells. However, at $1000 \mu \mathrm{g} / \mathrm{ml}$, MNPs cause a significant cell viability decrease at both $24 \mathrm{~h}$ and $48 \mathrm{~h}$ of incubation.

The cytotoxicity assessment of free-BPPE and BPPE-CCMNPs at different concentrations on MDA-MB-231 and 4T1 cells revealed that both free-BPPE and BPPE-CCMNPs are toxic against cancerous cells. Significant toxic effect of free-BPPE and BPPE-CCMNPs on cancerous cells was initiated form $15 \mu \mathrm{g} / \mathrm{ml}$ at both $24 \mathrm{~h}$ and $48 \mathrm{~h}$ incubation. Moreover, the drug-loaded NPs (BPPE-CCMNPs) have shown more cytotoxicity against cancer cells comparing to free-BPPE. Interestingly, neither free-BPPE nor BPPE-CCMNPs show significant toxicity against NIH/3T3 normal cells at the same concentrations.

\section{LDH assay}

The cell membrane integrity study of the NIH/3T3 (Fig. 8a, b), MDA-MB-231 (Fig. 8c, d), and 4T1 (Fig. 8e, f) cells which were individually incubated with MNPs, free-BPPE, and BPPE-CCMNPs has been carried out by lactate dehydrogenase (LDH) assay. The untreated cells with fresh media have been selected as a control for each cell type study.

Evaluating 15-500 $\mu \mathrm{g} / \mathrm{ml}$ of MNPs incubated with NIH/3T3, MDA-MB-231, and 4T1 cells showed no significant cellular cytotoxicity, except at $1000 \mu \mathrm{g} / \mathrm{ml}$ that a significant LDH\% release was observed at both incubation times.

Treatment results of MDA-MB-231 and 4T1 cells with different concentrations of freeBPPE and BPPE-CCMNPs revealed significant toxicity against cancerous cells which was initiated at $15 \mu \mathrm{g} / \mathrm{ml}$ at both $24 \mathrm{~h}$ and $48 \mathrm{~h}$ incubation. Furthermore, the exposure
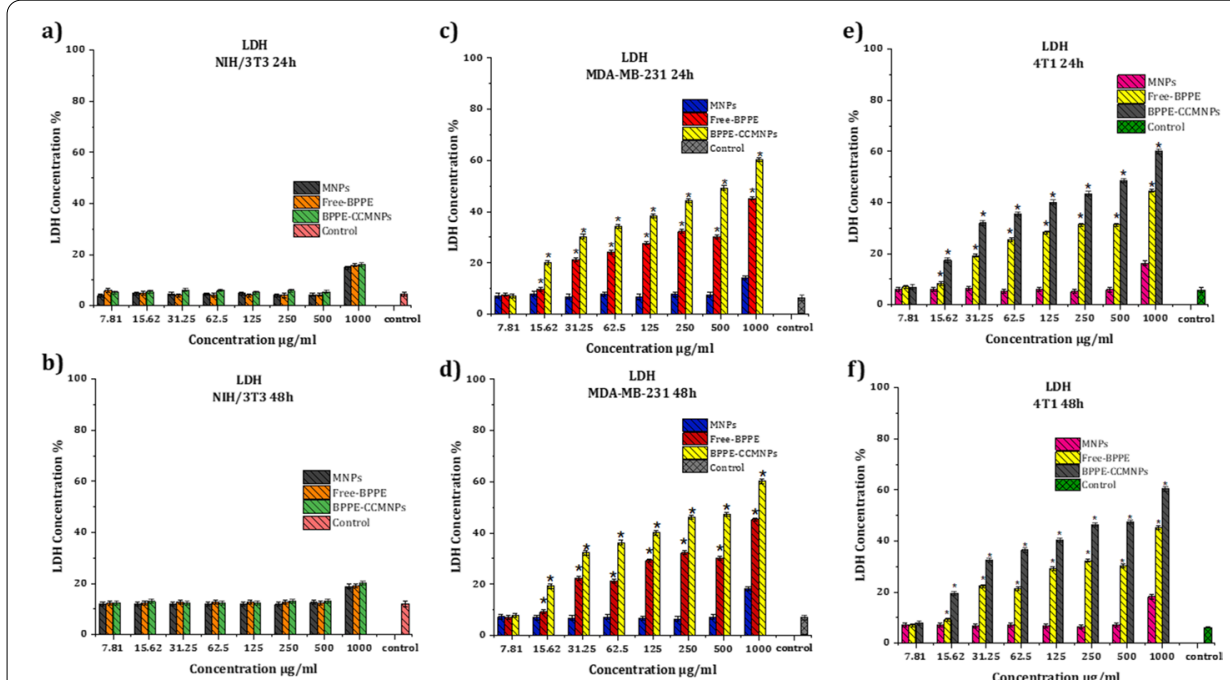

Fig. $8 \mathrm{LDH}$ release studies of $\mathbf{a}, \mathbf{b} \mathrm{NIH} / 3 \mathrm{~T} 3, \mathbf{c}, \mathbf{d} \mathrm{MDA}-\mathrm{MB}-231$, and $\mathbf{e}, \mathbf{f} 4 \mathrm{~T} 1$ cells expose to magnetic nanoparticles (MNPs), free black pomegranate peel extract (BPPE), and black pomegranate peel extract loaded chitosan-coated magnetic nanoparticles (BPPE-CCMNPs) with 1000 to $7.81 \mu \mathrm{g} / \mathrm{ml}$ concentration by serial dilution at $24 \mathrm{~h}$ and $48 \mathrm{~h}$ incubation. ${ }^{*} p \leq 0.05$ BPPE-CCMNPs versus free BPPE 
of the free-BPPE and BPPE-CCMNPs at same concentrations to NIH/3T3 normal cells showed no significant cytotoxicity at both $24 \mathrm{~h}$ and $48 \mathrm{~h}$.

\section{Discussion}

It is been believed that cancer is one of the principal causes of death around the globe. It is noteworthy to be mentioned that owing to modern therapeutics, the patients' care in such disease has been improved. Nevertheless, cancer at advanced metastatic stages is still untreatable. Therefore, finding a novel chemopreventive method should be a high priority of the researchers. Recently, several novel chemopreventive approaches with natural phytochemicals have been made for the prevention and treatment of cancer (Taherzadeh-Soureshjani and Chehelgerdi 2020). In the present study, core-shell NPs which consist of MNPs as core and chitosan layer as shell have been synthesized. The novel BPPE has been used as a loading drug to treat breast cancer cells and the cytotoxicity of the NPs (MNPs, BPPE-CCMNPs) and free drug (free-BPPE) have been studied by MTT and LDH assay on NIH/3T3, 4T1, and MDA-MB-231 cells. The synthesis of the NPs at each step was confirmed by various characterization methods. Evaluations on the size distribution of the nanoparticles by DLS have shown that the synthesized NPs, at each step of the synthesis, are in the range that could have a prolonged lifetime in blood circulation according to the studies carried out on the size effects of the NPs (Martinkova et al. 2018). Morphological studies by SEM revealed that the MNPs have been spherically formed. However, TEM images taken from BPPE-CCMNPs display mostly the core of the nanocomposite. This could be due to the collapse of the chitosan layer on the surface of the magnetic core on sample dispersion prior to the imaging step (Unsoy et al. 2014a). Nevertheless, images taken from the synthesized BPPE-CCMNPs show that they are roughly spherical in shape. Images achieved from AFM were on par with SEM and TEM results, but showed a bit of aggregation. Considering that the size of the synthesized nanoparticles has been studied by four different techniques, having a difference between the results achieved by different methods could be expected. In Contrary to microscopic techniques such as SEM, TEM, and AFM that use dried samples, DLS is an indirect method based on the determination of the frequency of movement and modeling of the hydrodynamic size from its data. Image analysis by microscopic methods such as TEM gives the true radius of the nanoparticles, but DLS results in hydrodynamic radius which is also sensitive to dynamic aggregation, aggregation, and agglomeration (Bootz et al. 2004; Souza et al. 2016; Eaton et al. 2017). For instance, a characterization study by Ding et al. on magnetic hybrid hollow spheres revealed average sizes of $160 \pm 19 \mathrm{~nm}$ and $171 \pm 30 \mathrm{~nm}$ that were achieved by TEM and AFM, respectively. The size distribution of such nanoparticles by DLS was about $200 \mathrm{~nm}$ which was higher than the microscopic method (Ding et al. 2006). In another study by Jaiswal et al., magnetically modalized poly ( $\mathrm{N}$-isopropyl acrylamide)-chitosan-based nanohydrogels were synthesized and the size distribution was studied by TEM, AFM, SEM, and DLS. Through microscopic studies, TEM showed 200-250 nm, SEM resulted in $170 \pm 20 \mathrm{~nm}$, and AFM revealed $190 \pm 15 \mathrm{~nm}$. However, size distribution by DLS showed $290 \mathrm{~nm}$ which was higher than the microscopic methods (Jaiswal et al. 2010). The synthesis of pure $\mathrm{Fe}_{2} \mathrm{O}_{3}$ NPs was confirmed by XRD (JCPDS card file No. 00-024-0072) (Joya et al. 2013). It could be determined from the diffraction peaks of the CCMNPs and BPPE-CCMNPs 
that the synthesized MNPs have sustained their purity after surface modification and drug loading step (Pham et al. 2016). The FT-IR graphs show typical vibration bands of the MNPs and CCMNPs according to other studies (Li et al. 2015; Pham et al. 2016). Due to the fact that black pomegranate peel extract is rich in phenolic compounds, the loading step was confirmed by the peaks attributing to the phenolic structures. This implies that the synthesized CCMNPs have properly been loaded with black pomegranate peel extract (Khorrami et al. 2019). The recorded zeta potential of the MNPs and CCMNPs manifested that the synthesized nanoparticles form a stable ferrofluid (Martinkova et al. 2018). Furthermore, assessments of the magnetic properties of the nanoparticles show that the MNPs have satisfactory magnetic potential. However, at the coating and drug loading step, the magnetic potential has gradually been decreased. The magnetic property reduction of the nanoparticles at these steps could potentially be due to the addition of the new layers which hinders the magnetic strength of the MNPs (Pham et al. 2016). Owing to the magnetic potential of the synthesized BPPE-CCMNPs, it could be used as targeted therapy by external magnetic field in breast cancer drug delivery for further studies (Foy et al. 2010).

Stability evaluation of the nanoparticles exhibits that MNPs which have negative zeta potential are much unstable and form larger aggregates in both serum-containing media which was on par with similar studies (Cohen et al. 2014). The BPPE-CCMNPs showed satisfactory stability and insignificant size growth in both serum-containing media at $24 \mathrm{~h}$ and $48 \mathrm{~h}$. On contrary, the drug-loaded nanoparticles were unstable in serum-free media and more prone to aggregation. The stability of the BPPE-CCMNPs in serumcontaining media could be due to NPs protein absorption causing electrostatic repulsion prior to NPs agglomeration. (Goycoolea et al. 2012; Moore et al. 2015).

According to studies carried out on the antioxidant activity of the compounds, the radical scavenging potential is directly associated with the amount of phenolic compounds in food material (Al-Dabbagh et al. 2019). Further studies have reported EC50 of 90 and $560 \mu \mathrm{g} / \mathrm{ml}$ for red pomegranate peel extract which could determine that BPPE has more radical scavenging potential compared to red pomegranate or other reported findings (Azarpazhooh et al. 2019; Benguiar 2020). In the matter of drug delivery by using MNPs as a core which provides the ability to target the tumor site by an external magnetic field, coating chitosan as a biodegradable shell could protect the magnetic core from oxidation, increase stability, and extended storage life. Moreover, chitosan provides various functional groups such as reactive hydroxyl and amino groups which cover and bind to the drug molecules leading to improve drug loading, controlled drug release, and drug efficiency (Assa et al. 2017). Studies on drug loading of the CCMNPs show rapid loading of BPEE at the first stages. However, when time passed, the absorption rate was moderately decreased. Since there was not much change in loading efficiency of the CCMNPs from 120 to $180 \mathrm{~min}$, it could accordingly be concluded that the CCMNPs have reached their maximum loading capacity. This could be due to the incorporation of the polyphenols into the chitosan layer (Pham et al. 2016). Results from the in vitro drug release of the nanoparticles manifested that BPPE-CCMNPs have the highest release ratio at $\mathrm{pH}$ 5 compared to $\mathrm{pH} 6.8$ and 7.4. Considering that chitosan is a pH-sensitive polymer, low pHs protonate chitosan amino groups lead to a generation of swelling osmotic pressure and release of the drug (Berger et al. 2004; Gierszewska-Druzyńska et al. 2013). Thus, the 
synthesized BPPE-CCMNPs are believed to have an effective release in the tumor microenvironment due to the increase of the drug release at low pHs. The MTT and LDH assay studies show that the free BPPE and BPPE-CCMNPs are toxic against MDA-MB-231 and $4 \mathrm{~T} 1$ cancerous cells. The BPPE-CCMNPs show more cytotoxicity compared with free BPPE. Results show that BPPE-CCMNPs cause more significant cell viability reduction from 15 to $1000 \mu \mathrm{g} / \mathrm{ml}$ on both MDA-MB-231 and $4 \mathrm{~T} 1$ cells at $24 \mathrm{~h}$ and $48 \mathrm{~h}$ incubation in comparison to free BPPE. According to the studies on the pomegranate peel extract, the existing phenolic acids and flavonoids are presented in soluble-free, soluble esterified, and insoluble-bound forms. Although it has been reported that the total free soluble phenolic and flavonoid compounds are higher than their insoluble-bound form, some of the hydroxybenzoic acid derivatives have insoluble bonds (Ambigaipalan et al. 2016; Gulsunoglu et al. 2019). The insoluble bonds could make it difficult for the BPPE to dissolve in cell media that leads to higher cell viability compared to BPPE-CCMNPs. On the other hand, CCMNPs cover the BPPE to avoid additional molecular reactions and increase the efficiency of the drug. It has been determined that the CCMNPs can have interaction with the negative domain of the cell membrane by electrostatic interactions owing to the positive zeta potential of the CCMNPs (Unsoy et al. 2014b). Furthermore, they are taken up by cells through endocytosis, in which the pathway begins at a pH of 7.4 and ends at $\mathrm{pH} 4.5$ in lysosomes that most of the BPPE from CCMNPs would release (Unsoy et al. 2014a). Cytotoxicity studies on bortezomib as a highly waterinsoluble drug in free form and loaded to CCMNPs also revealed that IC50 of the drugloaded CCMNPs was much lower than the free drug which demonstrates the role of CCMNPs in drug efficiency improvement (Unsoy et al. 2014b). Interestingly, neither free BPPE nor BPPE-CCMNPs show significant cytotoxicity on normal cells. However, at the highest concentration $(1000 \mu \mathrm{g} / \mathrm{ml})$, a significant cell viability decrease was observed in $\mathrm{NIH} / 3 \mathrm{~T} 3$ normal cells at both $24 \mathrm{~h}$ and $48 \mathrm{~h}$ of incubation time. Considering that the radical scavenging activity is associated with the inhibition of cancerous cells, it could be expected that the BPPE and BPPE-CCMNPs with such antioxidant potential show significant anticancer activity (Grigalius and Petrikaite 2017; Al-Dabbagh et al. 2019). It is proven by several studies that polyphenols and flavonoids have a toxic effect against cancerous cells but do not affect normal cells (Li et al. 2006; Dai and Mumper 2010). The reason for such a phenomenon is that the cancerous cells, but not normal cells, express active NF- $\kappa B$ that plays a mediatory role in their survival (Song et al. 2018). Furthermore, BPPE could suppress NF- $\mathrm{kB}$ regulated gene expression and decrease RhoC and RhoA protein expression which leads to suppression of the proliferation of the cancerous cells (Khan et al. 2009, 2012; Syed et al. 2013). For instance, Song et al. have synthesized magnetic alginate chitosan NPs and used curcumin as a polyphenol-rich compound as a loading drug. Cellular uptake results on MDA-MB-231 and HDF cells have revealed that at the highest studied concentration, about $80 \%$ and $50 \%$ of curcumin and curcuminloaded NPs are taken up by MDA-MB-231 and HDF cells, respectively (Song et al. 2018). The cytotoxicity studies showed that neither curcumin nor the drug-loaded NPs were toxic against HDF normal cells, but significant toxicity was observed in MDA-MB-231. Although nanoparticles have been used in clinical trials and approved for limited applications, cytotoxicity remains the greatest concern (Esfandiari et al. 2019). The synthesized MNPs exhibit no significant toxicity against NIH/3T3, 4T1, and MDA-MB-231 
cells, except at $1000 \mu \mathrm{g} / \mathrm{ml}$ that a significant cell viability decrease was observed at $24 \mathrm{~h}$ and $48 \mathrm{~h}$ of incubation. The above results suggest that the synthesized MNPs are biocompatible and could provide effective therapeutic actions, without affecting normal cells (Roy et al. 2003; Vijayan et al. 2018). Comparing with nanocarrier-loaded standard chemotherapeutics, Rahimi et al. have synthesized dendric chitosan grafted polyethylene glycol MNPs and used doxorubicin and methotrexate as the loading agents. The combination of the two chemotherapeutic drugs loaded to NPs at $5 \mu \mathrm{g} / \mathrm{ml}$ caused MCF-7 cell viability reduction to about $30 \%$ after $48 \mathrm{~h}$ of incubation (Rahimi et al. 2017). In another study, Vijayan et al. evaluated paclitaxel-loaded poly (lactic-co-glycolic acid) NPs on different MDA-MB cell series. At the concentration of $10 \mu \mathrm{g} / \mathrm{ml}$, the cell viability of the MDA-MB-157, MDA-MB-231, MDA-MB-435, MDA-MB-436, and MDA-MB-468 incubated with paclitaxel-loaded NPs were $44.4 \pm 1.2 \%, 34.6 \pm 0.8 \%, 42.4 \pm 1.4 \%, 35.3 \pm 0.8 \%$, $55.2 \pm 0.8 \%$, in that respect (Vijayan et al. 2018).

\section{Conclusions}

In this report, core-shell nanoparticles were synthesized and used as a drug carrier. The selected drug, which is the first time used in this nanocarrier for therapeutic applications, was derived from black pomegranate peel extract which has a great anticancer activity. The characterization studies manifested that the synthesized nanoparticles were pure, had no phase change through the coating and loading step, having a size range that could have prolonged half-life, and also maintain their stability in biological fluids. The synthesized nanocarriers had good loading efficiency and a great release ratio in tumor environment simulation. Cytotoxicity reports revealed that the synthesized nanocarrier are biocompatible and show no significant toxicity against normal and cancerous cells. Furthermore, BPPE the BPPE-CCMNPs were toxic against cancerous cells but not normal cells which are more promising than chemotherapeutic drugs. The use of such nanocarriers has promoted drug efficiency and could accordingly be used for highly insoluble drugs. Since the synthesized nanoparticles are applicable in drug delivery and the studied drug has a high anticancer effect and harmless against normal cells, the effect of other medicinal plants on cancer with the aid of nano-drug delivery should be studied.

\section{Materials and methods}

\section{Materials}

Black pomegranate fruit was purchased from an organic fruit market, Tehran, Iran. All selected reagents in this research were analytical grade and used without further purification. Iron (II) chloride $\left(\mathrm{FeCl}_{2}\right)$, Iron (III) chloride $\left(\mathrm{FeCl}_{3}\right)$, Chitosan [mol. wt.: $375 \mathrm{kDa}$, viscosity: 200-800 Kcps; 90\% deacetylated; soluble in dilute aqueous acid (pH 6.5)], citric acid $(0.5 \mathrm{~g} / \mathrm{ml})$, and alcohol (96\% pure) were purchased from Merck (Darmstadt, Germany). Ammonia solution (25\%), glacial acetic acid (99\% pure), and glutaraldehyde solution (25\%, MW:100.12) were supplemented from Sigma-Aldrich, France. Phosphate buffer saline powder (PBS) was bought from DNA biotech, Iran. Cell culture medium including RPMI and DMEM, Penicillin-Streptomycin $(10,000 \mu \mathrm{g} / \mathrm{ml})$, and fetal bovine serum (FBS) have been supplied from Gibco, United Kingdom. 3-[4,5-Dimethylthiazol2-yl]-2,5-diphenyltetrazolium bromide (MTT) standard kit was supplied from Merck 
Japan. Lactate dehydrogenase commercial kit was supplied from Promega, Germany. DPPH assay kit and dimethyl sulfoxide (DMSO) (Hybri-Max ${ }^{\mathrm{TM}}$ grade, quality level 400) were purchased from Sigma-Aldrich, Germany. Also, NIH/3T3, MDA-MB-231, and 4T1 cell lines were supplemented by Royan Institute, Tehran, Iran.

\section{Synthesis of MNPs}

The solution was prepared by adding $4.4 \mathrm{~g}$ of $\mathrm{FeCl}_{3}$ and $1.7 \mathrm{~g}$ of $\mathrm{FeCl}_{2}$ in $80 \mathrm{ml}$ of distilled water. The temperature was gradually increased to $70{ }^{\circ} \mathrm{C}$ with $1000 \mathrm{rpm}$ mechanical stirring under the reflux condition of the nitrogen atmosphere. The condition was preserved for $30 \mathrm{~min}$ and then $20 \mathrm{ml}$ of ammonia was added immediately. The solution was stirred in the same condition for another $30 \mathrm{~min}$. Following this step, $4 \mathrm{ml}$ of aqueous citric acid $(0.5 \mathrm{~g} / \mathrm{ml})$ was added to the solution and the temperature was slowly reached to $90{ }^{\circ} \mathrm{C}$ and stirred for $60 \mathrm{~min}$. The solution was then cooled down to room temperature and washed off by magnetic decantation with distilled water and alcohol (Nigam et al. 2011). The black precipitate powder was achieved when the solution was freeze-dried.

\section{Synthesis of CCMNPs}

First, $3 \mathrm{~g}$ of chitosan was dissolved in $300 \mathrm{ml}$ of distilled water containing $3 \mathrm{ml}$ of glacial acetic acid. The solution was homogenized with Ultrasonic Homogenizer, Sonicator-250 W (BEM250A) for $15 \mathrm{~min}$ and then was stirred at $1000 \mathrm{rpm}$ for $18 \mathrm{~h}$. Then, $0.15 \mathrm{~g}$ of MNPs was dissolved in $300 \mathrm{ml}$ of distilled water and then was sonicated for $5 \mathrm{~min}$. The dissolved MNPs were then added to the prepared chitosan solution and its $\mathrm{pH}$ was recorded ( $\mathrm{pH} 4-5)$. The mixture was stirred for $6 \mathrm{~h}$ at $1000 \mathrm{rpm}$ and $0.6 \mathrm{ml}$ of glutaraldehyde was then added. The solution was stirred for 3 more hours at $1000 \mathrm{rpm}$ and washed off by magnetic decantation. The powder was achieved by a freeze dryer (Sureshkumar et al. 2016).

\section{Characterization of the materials}

DLS which measures nanoparticle size in liquid media and zeta potential (the surface charge of the nanoparticles) were recorded with an SZ-100V2 nanoparticle analyzer (Horiba). FT-IR which determines the surface chemistry of the nanoparticles was carried out by BRUKER-27 TENSOR. XRD was measured by XRD Philips PW1730. The magnetic properties of the nanoparticles were assessed by VSM NMI-Nanomagnetics-Instrument at room temperature. Morphological properties of the materials were recorded with field emission scanning electron microscopy (FE-SEM) by SEM (TESCAN MIRA3), AFM by DME instrument (Dualscope C-26 with DME-SPM 2.1.1.2 software), and high-resolution transmission electron microscopy (HR-TEM) by TEM FEI TEC9G20.

\section{Stability of the nanoparticles in cell media}

Stability characterization of the synthesized nanoparticles in cell media was performed by measuring the hydrodynamic size of the nanoparticles with DLS and their surface charge with Zeta sizer in serum-containing (cell media +10\%FBS) and serum-free (cell media without FBS) cell media. RPMI that was used for 4T1 and MDA-MB-231 cells and DMEM as the NIH/3T3 cell culture media were selected for this study. The solutions 
were prepared by adding MNPs and BPPE-CCMNPs into RPMI, RPMI + 10\% FBS, DMEM, and DMEM + 10\% FBS forming a $1 \mathrm{mg} / \mathrm{ml}$ concentration. The solutions were sonicated to aid in mixing and homogenous dispersion and incubated at $37{ }^{\circ} \mathrm{C}$ for $24 \mathrm{~h}$ and $48 \mathrm{~h}$.

\section{Preparation of BPPE}

The black pomegranate fruits were assessed and selected by the condition of their peels. Following the peeling step, the achieved peels were dried at room temperature. The dried peels were then ground by a vibratory sieve shaker (Fritsch ANALYSETTE 3 PRO). To extract the existing compound of the peels, $0.1 \mathrm{~g}$ of BPP was added to the solution containing $80 \mathrm{ml}$ of ethanol and $20 \mathrm{ml}$ of water. The mixture was then sonicated for $8 \mathrm{~min}$ and purified using Whatman qualitative filter paper Grade. 1 (Merck, Germany) (Zhang et al. 2018; Khorrami et al. 2019).

\section{In vitro BPPE drug loading and release studies}

The BPPE loading phase was performed by dissolving $0.3 \mathrm{~g}$ of CCMNPs into a prepared 0.1\% BPPE solution (Pham et al. 2016). The mixture was first sonicated for $5 \mathrm{~min}$ and then stirred for $3 \mathrm{~h}$ at $1000 \mathrm{rpm}$ to increase nanoparticles drug absorption. The loading efficiency was carried out by separating nanoparticles from the solution by using a magnet. At each fixed period of time, the absorbance of the residual BPPE was measured at $\lambda_{\max }=370 \mathrm{~nm}$ by UV-spectrophotometer (PerkinElmer LS 45 fluorescence spectrophotometer) and generating calibration curve. The encapsulation efficiency (EE) of the nanoparticles was calculated by Eq. (1) and the ratio of the loaded drug per weight unit of the nanoparticles, loading capacity (LC), was obtained by Eq. (2) (Prabha and Raj 2016):

$$
\begin{aligned}
& \% \mathrm{EE}=\frac{W_{t}-W_{f}}{W_{t}} \times 100, \\
& \% \mathrm{LC}=\frac{W_{t}-W_{f}}{W_{n}} \times 100 .
\end{aligned}
$$

From the above equations, $W_{\mathrm{t}}$ is the amount of BPP powder added to the solution and $W_{\mathrm{f}}$ indicates the free BPPE in the supernatant. Also, $W_{\mathrm{n}}$ is accounted as the weight of the nanoparticles added to the solution.

Following the loading phase, the solution was rotated at $40{ }^{\circ} \mathrm{C}$ and 150 cycles $/ \mathrm{min}$ by (Heidolph Hei-VAP) Core Rotary evaporator to obtain BPPE-CCMNPs powder. The release profile of the BPPE drug was evaluated by adding $0.1 \mathrm{mg}$ of BPPE-CCMNPs in $10 \mathrm{ml}$ of PBS (Prabha and Raj 2016) at pH of 5, 6.8, 7.4 which mimics the environments of endochylema of cancer cells, interstitial fluid, and physiological environment. The solutions were moved to a shaker incubator at $150 \mathrm{cycles} / \mathrm{min}$ and at $37^{\circ} \mathrm{C}$. At each fixed time interval, the BPPE-CCMNPs were separated from the solution by magnetic decantation and the absorbance of the released BPPE in the supernatant was recorded at $\lambda_{\max }=375 \mathrm{~nm}$ by a UV-spectrophotometer. Quantification of released BPPE was performed by generating a calibration curve. The release rate of BPPE was determined from the following Eq. (3) with known amount of drug concentrations (Sanoj Rejinold et al. 
Release ratio $\%=\frac{\text { Released BPPE from BPPE }- \text { CCMNPs }}{\text { Total amount of BPPE in BPPE }- \text { CCMNPs }} \times 100$

\section{Radical scavenging activity (RSA)}

The free radical scavenging capacity of the BPPE was carried out by using DPPH assay. The concentration of the samples (1.96 to $500 \mu \mathrm{g} / \mathrm{ml}$ ) was built in DMSO by serial dilution. Then $1900 \mu \mathrm{L}$ of DPPH $(0.1 \mathrm{mM}$ in ethanol) was added to $100 \mu \mathrm{L}$ of the prepared solutions. The solutions were incubated for $20 \mathrm{~min}$ in a dark room and centrifuged for $2 \mathrm{~min}$ at 12,000 rpm. The efficiency of the BPPE antioxidant activity was then measured by Eq. (4) (Boylan et al. 2015) using UV-spectrophotometer at $\lambda_{\max }=517 \mathrm{~nm}$. Also, the solutions containing DMSO and $1900 \mu \mathrm{L}$ of DPPH were considered as blank and control, respectively.

$$
\% \text { RSA }=\frac{\text { Absorbance }_{\text {Sample }}-\text { Absorbance }_{\text {Blank }}}{\text { Absorbance }_{\text {Control }}} \times 100
$$

\section{In vitro cytotoxicity assay}

The in vitro cytotoxicity of the free BPPE, BPPE loaded-CCMNPs, and MNPs against NIH/3T3, 4T1, MDA-MB-231 cell lines were evaluated by using standard MTT [3-[4,5-Dimethylthiazol-2-yl]-2,5-diphenyltetrazolium bromide] assay (Merck, Japan). 4T1 and MDA-MB-231 cells were cultured in RPMI and NIH/3T3 was cultured in DMEM. The cells were then moved to 96 well plates with $2 \times 10^{5}$ cells in each well and incubated. Following this step, the cell media were removed and replaced with media containing 1000 to $7.8 \mu \mathrm{g} / \mathrm{ml}$ of BPPE, BPPE-loaded-CCMNPs, and MNPs, which were prepared by serial dilution (Khorrami et al. 2019; Fatahi et al. 2020). After each period of incubation ( $24 \mathrm{~h}$ and $48 \mathrm{~h}$ ), the cell media were removed and replaced with PBS dissolved MTT $(5 \mathrm{mg} / \mathrm{ml})$ and incubated for $4 \mathrm{~h}$. The MTT salt was afterward washed out with DMSO and the optical density of the samples was recorded by ELISA plate reader (ELX 808 IU Biotek) at $\lambda_{\max }=570 \mathrm{~nm}$. The untreated cells have been selected as the control for this study. The concentrations of the MNPs, BPPE-CCMNPs, and the free BPPE were performed in triplicate and repeated three individual times. The cell viability ratio was related to the control wells that contain untreated cells with fresh cell culture medium for each type of cell and calculated by the following formula (5):

$$
\text { Cell viability (\%): } \frac{\text { Absorption }_{\text {Test }}}{\text { Absorption }_{\text {Control }}} \text {. }
$$

\section{Lactate dehydrogenase (LDH) assay}

To assess the cell membrane integrity, the LDH enzyme activity which is soluble in the cytosol was carried out with Promega LDH kit (Germany) followed by (Esfandiari et al. 2019). The NIH/3T3, 4T1, and MDA-MB-231 cells were first incubated with different concentrations $(1000 \mu \mathrm{g} / \mathrm{ml}$ to $7.81 \mu \mathrm{g} / \mathrm{ml})$ of MNPs, BPPE-CCMNPs, and free BPPE which were made by serial dilution (Khorrami et al. 2019; Fatahi et al. 2020). 
After $24 \mathrm{~h}$ and $48 \mathrm{~h}$ incubation, the LDH activity was assayed in $100 \mu \mathrm{L}$ medium. The optical density of the samples was then determined at $\lambda_{\max }=490 \mathrm{~nm}$ by an ELISA microplate reader (ELX 808 IU Biotek). Also, the untreated cells have been accounted as the control in this test. The concentrations of the MNPs, BPPE-CCMNPs and the free BPPE were performed in triplicate and repeated three times. The LDH concentration (\%) was associated with control cells containing untreated cells for each type with fresh cell media and has been calculated by the following formula (6):

$$
\text { LDH Concentration(\%): } \frac{\text { Absorption }_{\text {Test }}}{\text { Absorption }_{\text {Control }}}
$$

\title{
Statistical analysis
}

The achieved data have been analyzed using analysis of variance (ANOVA) followed by LSD post hoc test, in SPSS 27. Results have been reported as mean \pm SEM. Significance was defined as $p \leq 0.05$. All experiments have been performed in triplicate and repeated three times.

\begin{abstract}
Abbreviations
WHO: World Health Organization; ACS: American Cancer Society; NPs: Nanoparticles; MNPs: Magnetic nanoparticles; SPIONs: Superparamagnetic iron oxide nanoparticles; MRI: Magnetic resonance imaging; BPP: Black peel pomegranate; BP: Black pomegranate; CCMNPs: Chitosan-coated magnetic nanoparticles; BPPE: Black pomegranate peel extract; BPPE-CCMNPs: Black pomegranate loaded chitosan-coated magnetic nanoparticles; DLS: Dynamic light scattering; AFM: Atomic force microscopy; SEM: Scanning electron microscopy; TEM: Transmission electron microscopy; RPMI: Roswell Park Memorial Institute; DMEM: Dulbecco's modified Eagle medium; DI water: Deionized water; RSA: Radical scavenging activity; DPPH: 2,2-Diphenyl-1-picrylhydrazyl; EC50: Effective concentration; FT-IR: Fourier transform infrared spectroscopy; XRD: X-ray diffraction; VSM: Vibrating sample magnetometer; MTT: 3-(4,5-Dimethylthiazol-2-YI)-2,5-diphenyltetrazolium Bromide; LDH: Lactate dehydrogenase; PBS: Phosphate buffer salin; FBS: Fetal bovine serum; DMSO: Dimethylsulfoxide; FE-SEM: Field emission scanning electron microscopy; HR-TEM: High-resolution transmission electron microscopy; EE: Encapsulation efficiency; LC: Loading capacity.
\end{abstract}

\section{Acknowledgements}

Not applicable

\section{Authors' contributions}

AT: investigation, validation, formal analysis, visualization, writing original draft; NE: analysis, validation, methodology, project administration, supervision, review, and editing of the original draft; SR: review, editing, analyzing, and interpreting the data. All authors read and approved the final manuscript.

\section{Funding}

The authors received no funding from an external source.

Availability of data and materials

The datasets used and/or analyzed during the current study are available from the corresponding author on reasonable request.

\section{Declarations}

Ethics approval and consent to participate

Not applicable.

\section{Consent for publication}

Not applicable.

Competing interests

The authors declare that they have no competing interests.

\section{Author details}

${ }^{1}$ Faculty of Life Sciences and Biotechnology, Shahid Beheshti University, Tehran, Iran. ${ }^{2}$ Department of Organic Colorants, Institute for Color Science and Technology, Tehran, Iran. 
Received: 6 January 2021 Accepted: 28 June 2021

Published online: 08 July 2021

\section{References}

Al-Dabbagh B, Elhaty IA, Elhaw M, et al. Antioxidant and anticancer activities of chamomile (Matricaria recutita L.). BMC Res Notes. 2019;12:3. https://doi.org/10.1186/s13104-018-3960-y.

Ambigaipalan P, de Camargo AC, Shahidi F. Phenolic compounds of pomegranate byproducts (outer skin, mesocarp, divider membrane) and their antioxidant activities. J Agric Food Chem. 2016;64:6584-604. https://doi.org/10.1021/ acs.jafc.6b02950.

Assa F, Jafarizadeh-Malmiri H, Ajamein $\mathrm{H}$, et al. Chitosan magnetic nanoparticles for drug delivery systems. Crit Rev Biotechnol. 2017;37:492-509. https://doi.org/10.1080/07388551.2016.1185389.

Azarpazhooh E, Sharayei P, Zomorodi S, Ramaswamy HS. Physicochemical and phytochemical characterization and storage stability of freeze-dried encapsulated pomegranate peel anthocyanin and in vitro evaluation of its antioxidant activity. Food Bioprocess Technol. 2019;12:199-210. https://doi.org/10.1007/s11947-018-2195-1.

Benguiar R. Phytochemical analysis, antibacterial and antioxidant activities of pomegranate (Punica granatum L.) peel extracts. Int J Biosci. 2020. https://doi.org/10.12692/ijb/16.6.35-44.

Berger J, Reist M, Mayer JM, et al. Structure and interactions in covalently and ionically crosslinked chitosan hydrogels for biomedical applications. Eur J Pharm Biopharm. 2004;57:19-34. https://doi.org/10.1016/S0939-6411(03)00161-9.

Bobo D, Robinson KJ, Islam J, et al. Nanoparticle-based medicines: a review of FDA-approved materials and clinical trials to date. Pharm Res. 2016;33:2373-87. https://doi.org/10.1007/s11095-016-1958-5.

Bootz A, Vogel V, Schubert D, Kreuter J. Comparison of scanning electron microscopy, dynamic light scattering and analytical ultracentrifugation for the sizing of poly(butyl cyanoacrylate) nanoparticles. Eur J Pharm Biopharm. 2004:57:369-75. https://doi.org/10.1016/S0939-6411(03)00193-0.

Boylan F, Menezes S, Leita GG. Screening of Brazilian plant extracts for antioxidant activity by the use of DPPH free radical method. Phytother Res. 2015;130:127-30. https://doi.org/10.1002/ptr.687.

Bray F, Ferlay J, Soerjomataram I, et al. Global cancer statistics 2018: GLOBOCAN estimates of incidence and mortality worldwide for 36 cancers in 185 countries. CA Cancer J Clin. 2018;68:394-424. https://doi.org/10.3322/caac.21492.

Chanphai P, Tajmir-Riahi HA. Chitosan nanoparticles conjugate with trypsin and trypsin inhibitor. Carbohydr Polym. 2016;144:346-52. https://doi.org/10.1016/j.carbpol.2016.02.066.

Chen H, Zhang W, Zhu G, et al. Rethinking cancer nanotheranostics. Nat Rev Mater. 2017;2:17024. https://doi.org/10. 1038/natrevmats.2017.24.

Chidambara Murthy KN, Jayaprakasha GK, Singh RP. Studies on antioxidant activity of pomegranate (Punica granatum) peel extract using in vivo models. J Agric Food Chem. 2002;50:4791-5. https://doi.org/10.1021/jf0255735.

Cohen JM, Teeguarden JG, Demokritou P. An integrated approach for the in vitro dosimetry of engineered nanomaterials. Part Fibre Toxicol. 2014;11:20. https://doi.org/10.1186/1743-8977-11-20.

Dai J, Mumper RJ. Plant phenolics: extraction, analysis and their antioxidant and anticancer properties. Molecules. 2010;15:7313-52. https://doi.org/10.3390/molecules15107313.

Deng Y, Li Y, Yang F, et al. The extract from Punica granatum (pomegranate) peel induces apoptosis and impairs metastasis in prostate cancer cells. Biomed Pharmacother. 2017;93:976-84. https://doi.org/10.1016/j.biopha.2017.07.008.

Ding Y, Hu Y, Zhang L, et al. Synthesis and magnetic properties of biocompatible hybrid hollow spheres. Biomacromol. 2006;7:1766-72. https://doi.org/10.1021/bm060085h

Eaton P, Quaresma P, Soares C, et al. A direct comparison of experimental methods to measure dimensions of synthetic nanoparticles. Ultramicroscopy. 2017:182:179-90. https://doi.org/10.1016/j.ultramic.2017.07.001.

Erofeev A, Gorelkin P, Garanina A, et al. Novel method for rapid toxicity screening of magnetic nanoparticles. Sci Rep. 2018;8:7462. https://doi.org/10.1038/s41598-018-25852-4.

Esfandiari N. Targeting breast cancer with bio-inspired virus nanoparticles. Arch Breast Cancer. 2018;5:90-5. https://doi. org/10.19187/abc.20185290-95.

Esfandiari N, Taherian A. Nanomedicine, a new therapeutic strategy in breast cancer treatment. Arch Breast Cancer. 2019;6:69-82. https://doi.org/10.32768/abc.20196269-82.

Esfandiari N, Arzanani MK, Soleimani M, et al. A new application of plant virus nanoparticles as drug delivery in breast cancer. Tumor Biol. 2016;37:1229-36. https://doi.org/10.1007/s13277-015-3867-3.

Esfandiari N, Arzanani MK, Koohi-Habibi M. The study of toxicity and pathogenicity risk of Potato Virus X/Herceptin nanoparticles as agents for cancer therapy. Cancer Nanotechnol. 2018;9:1. https://doi.org/10.1186/s12645-018-0036-6.

Esfandiari $\mathrm{N}$, Bagheri Z, Ehtesabi $\mathrm{H}$, et al. Effect of carbonization degree of carbon dots on cytotoxicity and photoinduced toxicity to cells. Heliyon. 2019. https://doi.org/10.1016/j.heliyon.2019.e02940.

Fatahi Z, Esfandiari N, Ranjbar Z. A new anti-counterfeiting feature relying on invisible non-toxic fluorescent carbon dots. J Anal Test. 2020;4:307-15. https://doi.org/10.1007/s41664-020-00149-6.

Fawole OA, Makunga NP, Opara UL. Antibacterial, antioxidant and tyrosinase-inhibition activities of pomegranate fruit peel methanolic extract. BMC Complement Altern Med. 2012;12:1178. https://doi.org/10.1186/1472-6882-12-200.

Fernandes DA, Kolios MC. Perfluorocarbon bubbles as photoacoustic signal amplifiers for cancer theranostics. Opt Mater Express. 2019a;9:4532. https://doi.org/10.1364/ome.9.004532.

Fernandes DA, Kolios MC. Near-infrared absorbing nanoemulsions as nonlinear ultrasound contrast agents for cancer theranostics. J Mol Liq. 2019b;287: 110848. https://doi.org/10.1016/j.molliq.2019.04.125.

Fischer UA, Carle R, Kammerer DR. Identification and quantification of phenolic compounds from pomegranate (Punica granatum L.) peel, mesocarp, aril and differently produced juices by HPLC-DAD-ESI/MSn. Food Chem. 2011;127:807-21. https://doi.org/10.1016/j.foodchem.2010.12.156.

Foy SP, Manthe RL, Foy ST, et al. Optical imaging and magnetic field targeting of magnetic nanoparticles in tumors. ACS Nano. 2010;4:5217-24. https://doi.org/10.1021/nn101427t. 
Gierszewska-Druzyńska M, Ostrowska-Czubenko J, Kwiatkowska A. Effect of ionic crosslinking on density of hydrogel chitosan membranes. Prog Chem Appl Chitin Deriv. 2013;18:49-58.

Gobbo OL, Sjaastad K, Radomski MW, et al. Magnetic nanoparticles in cancer theranostics. Theranostics. 2015;5:1249-63. https://doi.org/10.7150/thno.11544.

Goycoolea FM, Valle-Gallego A, Stefani R, et al. Chitosan-based nanocapsules: physical characterization, stability in biological media and capsaicin encapsulation. Colloid Polym Sci. 2012;290:1423-34. https://doi.org/10.1007/ s00396-012-2669-z.

Grigalius I, Petrikaite V. Relationship between antioxidant and anticancer activity of trihydroxyflavones. Molecules. 2017;22:2169. https://doi.org/10.3390/molecules22122169.

Gulsunoglu Z, Karbancioglu-Guler F, Raes K, Kilic-Akyilmaz M. Soluble and insoluble-bound phenolics and antioxidant activity of various industrial plant wastes. Int J Food Prop. 2019;22:1501-10. https://doi.org/10.1080/10942912.2019. 1656233.

Gurunathan S, Kang MH, Qasim M, Kim JH. Nanoparticle-mediated combination therapy: two-in-one approach for cancer. Int J Mol Sci. 2018;19:1-37. https://doi.org/10.3390/ijms19103264.

Hartshorn CM, Bradbury MS, Lanza GM, et al. Nanotechnology strategies to advance outcomes in clinical cancer care. ACS Nano. 2018;12:24-43. https://doi.org/10.1021/acsnano.7b05108.

Jaiswal MK, Banerjee R, Pradhan P, Bahadur D. Thermal behavior of magnetically modalized poly( $N$-isopropylacrylamide)chitosan based nanohydrogel. Colloids Surf B Biointerfaces. 2010;81:185-94. https://doi.org/10.1016/j.colsurfb.2010. 07.009.

Joya MR, Barón-Jaimez J, Barba-Ortega J. Preparation and characterization of $\mathrm{Fe}_{2} \mathrm{O}_{3}$ nanoparticles. J Phys Conf Ser. 2013;466: 012004. https://doi.org/10.1088/1742-6596/466/1/012004.

Kanatt SR, Chander R, Sharma A. Antioxidant and antimicrobial activity of pomegranate peel extract improves the shelf life of chicken products. Int J Food Sci Technol. 2010;45:216-22. https://doi.org/10.1111/j.1365-2621.2009.02124.X.

Kayal S, Ramanujan RV. Doxorubicin loaded PVA coated iron oxide nanoparticles for targeted drug delivery. Mater Sci Eng C. 2010;30:484-90. https://doi.org/10.1016/j.msec.2010.01.006.

Khan GN, Gorin MA, Rosenthal D, et al. Pomegranate fruit extract impairs invasion and motility in human breast cancer. Integr Cancer Ther. 2009;8:242-53. https://doi.org/10.1177/1534735409341405.

Khan N, Syed DN, Pal HC, et al. Pomegranate Fruit Extract Inhibits UVB-induced Inflammation and proliferation by modulating NF-KB and MAPK signaling pathways in mouse skint. Photochem Photobiol. 2012;88:1126-34. https://doi. org/10.1111/j.1751-1097.2011.01063.x.

Khorrami S, Zarepour A, Zarrabi A. Green synthesis of silver nanoparticles at low temperature in a fast pace with unique DPPH radical scavenging and selective cytotoxicity against MCF-7 and BT-20 tumor cell lines. Biotechnol Reports. 2019:24: e00393. https://doi.org/10.1016/j.btre.2019.e00393.

Larrosa M, González-Sarrías A, Yáñez-Gascón MJ, et al. Anti-inflammatory properties of a pomegranate extract and its metabolite urolithin-A in a colitis rat model and the effect of colon inflammation on phenolic metabolism $\boldsymbol{r}_{\text {. J Nutr }}$ Biochem. 2010;21:717-25. https://doi.org/10.1016/j.jnutbio.2009.04.012.

Lee JJ, Saiful Yazan L, Che Abdullah CA. A review on current nanomaterials and their drug conjugate for targeted breast cancer treatment. Int J Nanomedicine. 2017;12:2373-84. https://doi.org/10.2147/JJN.S127329.

Li Y, Guo C, Yang J, et al. Evaluation of antioxidant properties of pomegranate peel extract in comparison with pomegranate pulp extract. Food Chem. 2006;96:254-60. https://doi.org/10.1016/j.foodchem.2005.02.033.

Li S, Zhang T, Tang R, et al. Solvothermal synthesis and characterization of monodisperse superparamagnetic iron oxide nanoparticles. J Magn Magn Mater. 2015;379:226-31. https://doi.org/10.1016/j.jmmm.2014.12.054.

Martinkova P, Brtnicky M, Kynicky J, Pohanka M. Iron oxide nanoparticles: innovative tool in cancer diagnosis and therapy. Adv Healthc Mater. 2018;7:1700932. https://doi.org/10.1002/adhm.201700932.

Mazza G, Miniati E. Anthocyanins in fruits, vegetables, and grains. CRC Press; 2018.

Mohammed L, Gomaa HG, Ragab D, Zhu J. Magnetic nanoparticles for environmental and biomedical applications: a review. Particuology. 2017a;30:1-14. https://doi.org/10.1016/j.partic.2016.06.001.

Mohammed M, Syeda J, Wasan K, Wasan E. An overview of chitosan nanoparticles and its application in non-parenteral drug delivery. Pharmaceutics. 2017b;9:53. https://doi.org/10.3390/pharmaceutics9040053.

Moore TL, Rodriguez-Lorenzo L, Hirsch V, et al. Nanoparticle colloidal stability in cell culture media and impact on cellular interactions. Chem Soc Rev. 2015;44:6287-305. https://doi.org/10.1039/C4CS00487F.

Nigam S, Barick KC, Bahadur D. Development of citrate-stabilized $\mathrm{Fe}_{3} \mathrm{O}_{4}$ nanoparticles: conjugation and release of doxorubicin for therapeutic applications. J Magn Magn Mater. 2011;323:237-43. https://doi.org/10.1016/j.jmmm.2010.09. 009 .

Panth N, Manandhar B, Paudel KR. Anticancer activity of Punica granatum (Pomegranate): a review. Phyther Res. 2017;31:568-78. https://doi.org/10.1002/ptr.5784.

Patra $\mathrm{CR}$, Jing $Y$, Xu YH, et al. A core-shell nanomaterial with endogenous therapeutic and diagnostic functions. Cancer Nanotechnol. 2010;1:13-8. https://doi.org/10.1007/s12645-010-0002-4.

Pham XN, Nguyen TP, Pham TN, et al. Synthesis and characterization of chitosan-coated magnetite nanoparticles and their application in curcumin drug delivery. Adv Nat Sci Nanosci Nanotechnol. 2016;7: 045010. https://doi.org/10. 1088/2043-6262/7/4/045010.

Prabha G, Raj V. Preparation and characterization of polymer nanocomposites coated magnetic nanoparticles for drug delivery applications. J Magn Magn Mater. 2016;408:26-34. https://doi.org/10.1016/j.jmmm.2016.01.070.

Rahimi M, Safa KD, Salehi R. Co-delivery of doxorubicin and methotrexate by dendritic chitosan-g-mPEG as a magnetic nanocarrier for multi-drug delivery in combination chemotherapy. Polym Chem. 2017:8:7333-50. https://doi.org/10. 1039/C7PY01701D.

Roy K, Mukhopadhyay S, Mahmoodi-Meimand H. Leakage current mechanisms and leakage reduction techniques in deep-submicrometer CMOS circuits. Proc IEEE. 2003;91:305-27. https://doi.org/10.1109/JPROC.2002.808156.

Sanaeimehr Z, Javadi I, Namvar F. Antiangiogenic and antiapoptotic effects of green-synthesized zinc oxide nanoparticles using Sargassum muticum algae extraction. Cancer Nanotechnol. 2018;9:3. https://doi.org/10.1186/ s12645-018-0037-5. 
Sanoj Rejinold N, Muthunarayanan M, Divyarani W, et al. Curcumin-loaded biocompatible thermoresponsive polymeric nanoparticles for cancer drug delivery. J Colloid Interface Sci. 2011;360:39-51. https://doi.org/10.1016/j.jcis.2011.04. 006.

Senapati S, Mahanta AK, Kumar S, Maiti P. Controlled drug delivery vehicles for cancer treatment and their performance. Signal Transduct Target Ther. 2018;3:1-19. https://doi.org/10.1038/s41392-017-0004-3.

Shi J, Kantoff PW, Wooster R, Farokhzad OC. Cancer nanomedicine: progress, challenges and opportunities. Nat Rev Cancer. 2017;17:20-37. https://doi.org/10.1038/nrc.2016.108.

Siegel RL, Miller KD, Jemal A. Cancer statistics, 2015. CA Cancer J Clin. 2015;65:5-29. https://doi.org/10.3322/caac.21254. Siegel RL, Miller KD, Jemal A. Cancer statistics, 2016. CA Cancer J Clin. 2016;66:7-30. https://doi.org/10.3322/caac.21332. Siegel RL, Miller KD, Jemal A. Cancer statistics, 2017. CA Cancer J Clin. 2017;67:7-30. https://doi.org/10.3322/caac.21387. Siegel RL, Miller KD, Jemal A. Cancer statistics, 2018. CA Cancer J Clin. 2018:68:7-30. https://doi.org/10.3322/caac.21442. Siegel RL, Miller KD, Jemal A. Cancer statistics, 2019. CA Cancer J Clin. 2019;69:7-34. https://doi.org/10.3322/caac.21551. Siegel RL, Miller KD, Jemal A. Cancer statistics, 2020. CA Cancer J Clin. 2020;70:7-30. https://doi.org/10.3322/caac.21590

Singh AP, Biswas A, Shukla A, Maiti P. Targeted therapy in chronic diseases using nanomaterial-based drug delivery vehicles. Signal Transduct Target Ther. 2019;4:33. https://doi.org/10.1038/s41392-019-0068-3.

Song W, Su X, Gregory D, et al. Magnetic alginate/chitosan nanoparticles for targeted delivery of curcumin into human breast cancer cells. Nanomaterials. 2018;8:907. https://doi.org/10.3390/nano8110907.

Souza TGF, Ciminelli VST, Mohallem NDS. A comparison of TEM and DLS methods to characterize size distribution of ceramic nanoparticles. J Phys Conf Ser. 2016;733: 012039. https://doi.org/10.1088/1742-6596/733/1/012039.

Sureshkumar V, Kiruba Daniel SCG, Ruckmani K, Sivakumar M. Fabrication of chitosan-magnetite nanocomposite strip for chromium removal. Appl Nanosci. 2016;6:277-85. https://doi.org/10.1007/s13204-015-0429-3.

Syed D, Chamcheu J-C, Adhami V, Mukhtar H. Pomegranate extracts and cancer prevention: molecular and cellular activities. Anticancer Agents Med Chem. 2013;13:1149-61. https://doi.org/10.2174/1871520611313080003.

Taherzadeh-Soureshjani P, Chehelgerdi M. Algae-meditated route to cuprous oxide $\left(\mathrm{Cu}_{2} \mathrm{O}\right)$ nanoparticle: differential expression profile of MALAT1 and GAS5 LncRNAs and cytotoxic effect in human breast cancer. Cancer Nanotechnol. 2020;11:1-34. https://doi.org/10.1186/s12645-020-00066-4.

Tang X, Loc WS, Dong C, et al. The use of nanoparticulates to treat breast cancer. Nanomedicine. 2017;12:2367-88. https://doi.org/10.2217/nnm-2017-0202.

Unsoy G, Khodadust R, Yalcin S, et al. Synthesis of Doxorubicin loaded magnetic chitosan nanoparticles for $\mathrm{pH}$ responsive targeted drug delivery. Eur J Pharm Sci. 2014a;62:243-50. https://doi.org/10.1016/j.ejps.2014.05.021.

Unsoy G, Yalcin S, Khodadust R, et al. Chitosan magnetic nanoparticles for pH responsive Bortezomib release in cancer therapy. Biomed Pharmacother. 2014b;68:641-8. https://doi.org/10.1016/j.biopha.2014.04.003.

Vijayan V, Shalini K, Yugesvaran V, et al. Effect of paclitaxel-loaded PLGA nanoparticles on MDA-MB type cell lines: apoptosis and cytotoxicity studies. Curr Pharm Des. 2018;24:3366-75. https://doi.org/10.2174/13816128246661809031 10301.

Vini R, Sreeja S. Punica granatum and its therapeutic implications on breast carcinogenesis: a review. BioFactors. 2015;41:78-89. https://doi.org/10.1002/biof.1206.

Wild CP, Weiderpass E, Stewart BW. World Cancer report 2020: Cancer Research for Cancer Precention. Berlin: Springer; 2020.

Wiranowska M, Singh R, Falahat R, et al. Preferential drug delivery to tumor cells than normal cells using a tunable niosome-chitosan double package nanodelivery system: a novel in vitro model. Cancer Nanotechnol. 2020;11:3. https://doi.org/10.1186/s12645-020-00059-3.

Wu M, Huang S. Magnetic nanoparticles in cancer diagnosis, drug delivery and treatment (Review). Mol Clin Oncol. 2017. https://doi.org/10.3892/mco.2017.1399.

Xiong F, Huang S, Gu N. Magnetic nanoparticles: recent developments in drug delivery system. Drug Dev Ind Pharm. 2018:44:697-706. https://doi.org/10.1080/03639045.2017.1421961.

Zhang Q-W, Lin L-G, Ye W-C. Techniques for extraction and isolation of natural products: a comprehensive review. Chin Med. 2018;13:20. https://doi.org/10.1186/s13020-018-0177-x.

Zhao D, Yu S, Sun B, et al. Biomedical applications of chitosan and its derivative nanoparticles. Polymers (basel). 2018;10:462. https://doi.org/10.3390/polym10040462.

\section{Publisher's Note}

Springer Nature remains neutral with regard to jurisdictional claims in published maps and institutional affiliations.

Ready to submit your research? Choose BMC and benefit from:

- fast, convenient online submission

- thorough peer review by experienced researchers in your field

- rapid publication on acceptance

- support for research data, including large and complex data types

- gold Open Access which fosters wider collaboration and increased citations

- maximum visibility for your research: over 100M website views per year

At BMC, research is always in progress.

Learn more biomedcentral.com/submissions 